\title{
Route persistence. Modelling and quantifying historical route-network stability from the Roman period to early-modern times (AD 100-1600): a case study from the Netherlands
}

\author{
Rowin J. van Lanen ${ }^{1,2}$ • Bert J. Groenewoudt ${ }^{2}$. Theo Spek $^{3}$ - Esther Jansma ${ }^{1,2}$
}

Received: 23 July 2015 / Accepted: 31 October 2016/Published online: 18 November 2016

(C) The Author(s) 2016. This article is published with open access at Springerlink.com

\begin{abstract}
Research on route-network stability is rare. In time, due to cultural and/or natural causes, settlement locations and route orientation shift. The nature of these spatial changes sheds light on the complex interaction between settlements and surrounding natural landscape conditions. This study investigates the stability of route networks in the Netherlands during the past two millennia by determining their persistence through time. Environmental, archaeological and historical data are used to reconstruct and compare route networks. By using network friction, archaeological data on settlement patterns and route networks in combination with historical data (e.g. old maps), we were able to model route-network persistence (not necessarily continuity) from the Roman to early medieval periods (AD 100-800) and from the Early Middle Ages to the Early Modern Times (AD 800-1600). Results show that around $67.6 \%$ of the modelled early-medieval routes in the Netherlands are persistent with routes in the Roman period. Covering a much larger surface area of the Netherlands, $24.5 \%$ of the early-modern routes show a clear persistence with their early-medieval counterparts. Besides the differences in surface area, this downfall can largely be explained by cultural dynamics, with $71.4 \%$ of the earlymodern route network following modelled movement corridors already in existence during the Early Middle Ages.
\end{abstract}

Rowin J. van Lanen

r.j.vanlanen@uu.nl

1 Faculty of Geosciences, Utrecht University, P.O. Box 80.115, 3508 TC Utrecht, the Netherlands

2 Cultural Heritage Agency of the Netherlands, P.O. Box 1600, 3800 BP Amersfoort, the Netherlands

3 Faculty of Arts, Landscape History, University of Groningen, 9712 GK Groningen, the Netherlands
Keywords Route-network stability · Route persistence · Roman period · Early Middle Ages · Early-modern times · Historical routes

\section{Introduction}

The landscape in the Netherlands is best characterized as a dynamic lowland region partially influenced by marine and fluvial (e.g. Rhine and Meuse) processes and extensive peatlands. Throughout the Holocene, the low-lying western and northern, Holocene parts of the country have been subjected to frequent flooding (Stouthamer and Berendsen 2000; Erkens 2009; Vos et al. 2011; Cohen et al. 2012; Toonen 2013; Vos and De Vries 2013; Vos 2015). Somewhat higher Pleistocene soils can be found in the relatively more stable landscapes of the eastern and southern Netherlands (Steur and Heijink 1991; De Vries et al. 2003; Koomen and Maas 2004).

During the last 2000 years, the Dutch landscape changed rigorously (e.g. Jansma et al. 2014; Vos 2015). In the Roman and medieval periods, large parts of the western and northern Netherlands were covered by extensive peat bogs. From the 10th to 12th centuries onwards, large-scale dike building, drainage and reclamation starting in the western Netherlands made many of these peat landscapes much more accessible (Borger 1992; Gerding 1995; De Bont 2008). In addition, continuous oxidation of these peat soils, mainly through agricultural activities (drainage), caused subsidence (Vos and Van Heeringen 1997; Van Tielhof and Van Dam 2006; De Bont 2008) which in turn led to the construction of additional dikes. Although in recent years it has become increasingly clear that late Iron Age and Roman settlers in various parts of the coastal Netherlands have had a far stronger impact on their environment than previously assumed (Lascaris and De Kraker 2013), the influence of these small-scale reclamation areas on large- 
scale route networks will have been limited (Van Lanen et al. 2015a, b).

Landscape changes during the last two millennia must have had a major impact on the formation of route networks in the study area. In the lower Holocene parts, avulsion and marine processes continuously must have forced cultural adaptations until large-scale reclamation and dike building allowed inhabitants of the study area to increasingly control these landscape dynamics. In these earlier time intervals, landscape settings must have influenced the layout of past route networks to a considerable degree. In the relatively higher Pleistocene parts, more local and gradual geomorphological processes (e.g. peat growth, drainage) must have influenced these route networks in a similar manner but on a more local scale.

In order to deduce the relative impact of these influences, we will focus on land-route networks from the middle to late Roman period (ROM) (AD 70-450), the Early Middle Ages (EMA) (AD 450-1050) and Early Modern Times (EMT) (ca. AD 1600). Roman and early medieval route-network data in the study area were recently modelled by Van Lanen et al. (2015b). The earliest and therefore most EMA-compatible supra-regional overview of historical roads in the study area dates to the period around AD 1600, and from intermediate periods no data on route networks area available. The $\mathrm{AD}$ 1600 road data contain no information on water routes and therefore we exclusively compared land route networks. The central aim of this study is to determine the extent of route persistence and to quantify the role of landscape and cultural dynamics between these three time slices. Persistence in this context is defined as multiple-period route-section correlation. Another ambition of this research is to show the potential of integrating large datasets and the usefulness of an evidencebased approach when studying large-scale archaeological patterns such as historical route networks.

\section{Theoretical background}

Routes should not be regarded as straightforward, simple connections between individual settlements. Routes link settlements on a variety of scales (e.g. local, regional, supra-regional) and connect the actual settlement with surrounding natural landscapes. Therefore, route networks are the product of, and are influenced by, both cultural and natural dynamics. Researching route networks is therefore essential in order to fully understand the complex interaction between settlements and landscape dynamics.

Land-based unpaved route networks fundamentally differ from paved road networks. There is limited physical evidence for the existence of Roman roads in the Netherlands and even less for their existence during the EMA period. Whereas roads are fixed features connecting two places, routes are much more like movement corridors, i.e. zones in which people frequently travelled (Van Lanen et al. 2015b). ROM and EMA routes almost without exception were unpaved and not fixed to one location (e.g. Horsten 2005). Season-dependent conditions and general wear could force travellers to shift to adjacent lanes, thus creating route zones (Van Lanen et al. 2015b). In this respect, routes are spatially more dynamic than roads, but very similar in orientation. Whereas roads are rare in the ROM and EMA archaeological record, for the EMT period, an extensive road network has been recorded (Horsten 2005). In order to be able to compare EMT roads with the earlier route networks, they need to be standardized and converted to route zones ("Digitizing early-modern road networks" section).

Persistence between route networks is defined as the spatial correlation between individual route sections. The term "persistence" refers to the long-term use of specific locations, which not necessarily is equal to continuous use. We use this term in the sense of Schlanger's (1992) "persistent places", i.e. places that were "never" completely abandoned. Even if such locations (routes) temporarily are abandoned, they can be expected to survive in collective memory.

Landscapes are dynamic, constantly and inevitably changing through natural and cultural factors and the complex interaction between them (Fairclough 2007). As integral parts of the landscape, route networks are subjected to the same cultural and natural factors and as such provide a key to better understand the dynamic interplay between these factors. The study of large-scale route networks transcends the traditionally studied archaeological site level and focuses on both cultural and natural variables, thus requiring a landscapearchaeological approach.

In line with Barker (1986), Kluiving et al. (2012) and Kluiving and Guttmann-Bond (2012), landscape archaeology in the current paper is defined as the interdisciplinary investigation of the long-term relationship between people and their environment. The multitude of disciplines coming together in landscape archaeology have in common that past landscapes and their dynamics are studied as a single, complex site. "Landscape" in this context is best defined as "an area, as perceived by people, whose character is the result of the action and interaction of natural and/or human factors" (Council of Europe 2000). Studying the persistence of route networks requires an understanding of the natural and cultural processes within past landscapes. Landscape archaeology is multidisciplinary by nature and therefore is a perfect field for studying the interaction of natural and cultural processes.

Traditionally, GIS modelling of past routes largely has focussed on reconstructing routes and defining cost-surface modules (Zakšek et al. 2008; Herzog and Posluschny 2011, Murrieta-Flores 2012; Herzog 2013a, b, c; Verhagen 2013; Herzog 2014). Research on modelling large-scale route evolution and route persistence is rare. In dynamic lowland regions such as the Netherlands, landscape changes will have 
had a strong impact on route orientation through time. By combining network friction, i.e. calculated local accessibility based on a number of integrated-environmental datasets ("Network friction" section), with data on ROM and EMA route networks and with more recent maps, long-term changes in route networks can be modelled.

\section{Material}

\section{Network friction}

Network friction is the variable that determines regional accessibility based on local and surrounding landscape factors and that locates transport obstacles and possible movement corridors (Van Lanen et al. 2015a, p. 200-201). Through a network-friction analysis, Van Lanen et al. (2015a) determined potential movement corridors for ca. AD 100 and 800 (Fig. 1). This network-friction model (NFM) integrated palaeogeographical data from the ROM and EMA periods (Bos 2010; Vos et al. 2011; Cohen et al. 2012; Van Dinter 2013; Vos and De Vries 2013) with contemporary landscape data from the geomorphological and soil map of the Netherlands. The geomorphological map $(1: 50,000)$ contains information on the relief, age and genesis of landscape elements (Koomen and Excaltus 2003; Koomen and Maas 2004). The soil map $(1: 50,000)$ provides an overview of current soil types and groundwater averages in the Netherlands (Steur and Heijink 1991; De Vries et al. 2003; Van der Gaast et al. 2010). Landscape data postdating the EMA period were removed from datasets. Elevation data was added to the model for the Pleistocene soils through the height model of the Netherlands (Actueel Hoogtebestand Nederland-AHN) (Brand et al. 2003; Swart 2010; Van der Zon 2013).

\section{Archaeology and settlement data}

Archaeological data representing settlements were collected through the Archaeological Information System of the Netherlands (ARCHIS). ${ }^{1}$ This platform contains a national overview of recorded archaeological finds (Roorda and Wiemer 1992; Wiemer 2002). This dataset was enhanced through digitizing new research results published in available $\mathrm{PhD}$ theses, books and reports (Miedema 1983; Knol 1993; Bechert and Willems 1995; Verwers 1998; Van Beek 2009; Gerrets 2010; LGL World Heritage Database 2010; Verlinde and Hulst 2010; Dijkstra 2011 and Van der Velde 2011).

Settlement data for the EMT period were not available in ARCHIS and were collected using OpenStreetMap data on

\footnotetext{
${ }^{1}$ ARCHIS is maintained by the Cultural Heritage Agency of the Netherlands (RCE) and was created in 1992. Website: https://archis.cultureelerfgoed. $\mathrm{nl} / \# /$ login (accessed 25-06-2015).
}

current places in the Netherlands. ${ }^{2}$ Since most towns in the current Netherlands date back to before AD 1300, this dataset could be filtered to create a general overview of habitation around AD 1600 (Rutten and IJsselstijn 2014). Based on maps made by Prof. dr. Renes in part 2 and 4 of the Atlas van Nederland (1984), Histland ${ }^{3}$ data and the Archaeological Landscapes Map of the Netherlands, ${ }^{4}$ we excluded settlements located in parts of the country that were uncultivated during the EMT period (e.g. heathlands, younger reclamation areas).

\section{Past route networks}

Van Lanen et al. (2015b) modelled probable route networks for the ROM and EMA periods in the Netherlands (Fig. 1). Through combining network friction with archaeological data on settlements, burial sites and shipwrecks, interregional land and water routes were reconstructed. The route networks were validated against actual finds of infrastructure (e.g. roads, harbours, dikes, revetments) and isolated finds in the Netherlands for both periods. Results of Van Lanen et al. (2015b) prove promising, showing that $89.2 \%$ of the ROM and $85.4 \%$ of the EMA infrastructural finds were located within a $1000-\mathrm{m}$ modelled route zone.

\section{Topographic military maps 1850 (TMK 1850)}

The topographic military maps of 1850 (TMK 1850) first appeared between 1850 and 1864 (Van der Linden 1973; Wolters-Nordhoff 1990). The TMK $1850(1: 50,000)$ is the oldest nation-covering map of the Netherlands and was created by military reconnaissance officers between AD 1844 and 1852. Through thematic colouring, the TMK 1850 provides an extremely useful overview of the mid-nineteenth century landscape and urban development. Since industrialisation at the beginning of the twentieth century radically changed many parts of the Dutch landscape, these maps contain invaluable information on historical landscape elements that meanwhile have disappeared.

\section{Historical road data}

Historical roads were reconstructed by Horsten (2005) for the period between the sixteenth and nineteenth century. Mainly

\footnotetext{
${ }^{2}$ For more information on OpenStreet data and mapping, see www. openstreetmap.org (accessed 25-06-2015).

${ }^{3}$ Histland contains data on the reclamation and dynamics of the Dutch landscape. For more information, see http://landschapinnederland.nl/bronnen-enkaarten/histland (accessed 25-06-2015).

${ }^{4}$ This dataset was developed in 2015 by the Cultural Heritage Agency of the Netherland. Website: http://archeologieinnederland.nl/bronnen-enkaarten/archeologische-landschappenkaart (accessed on 25-06-2015).
} 

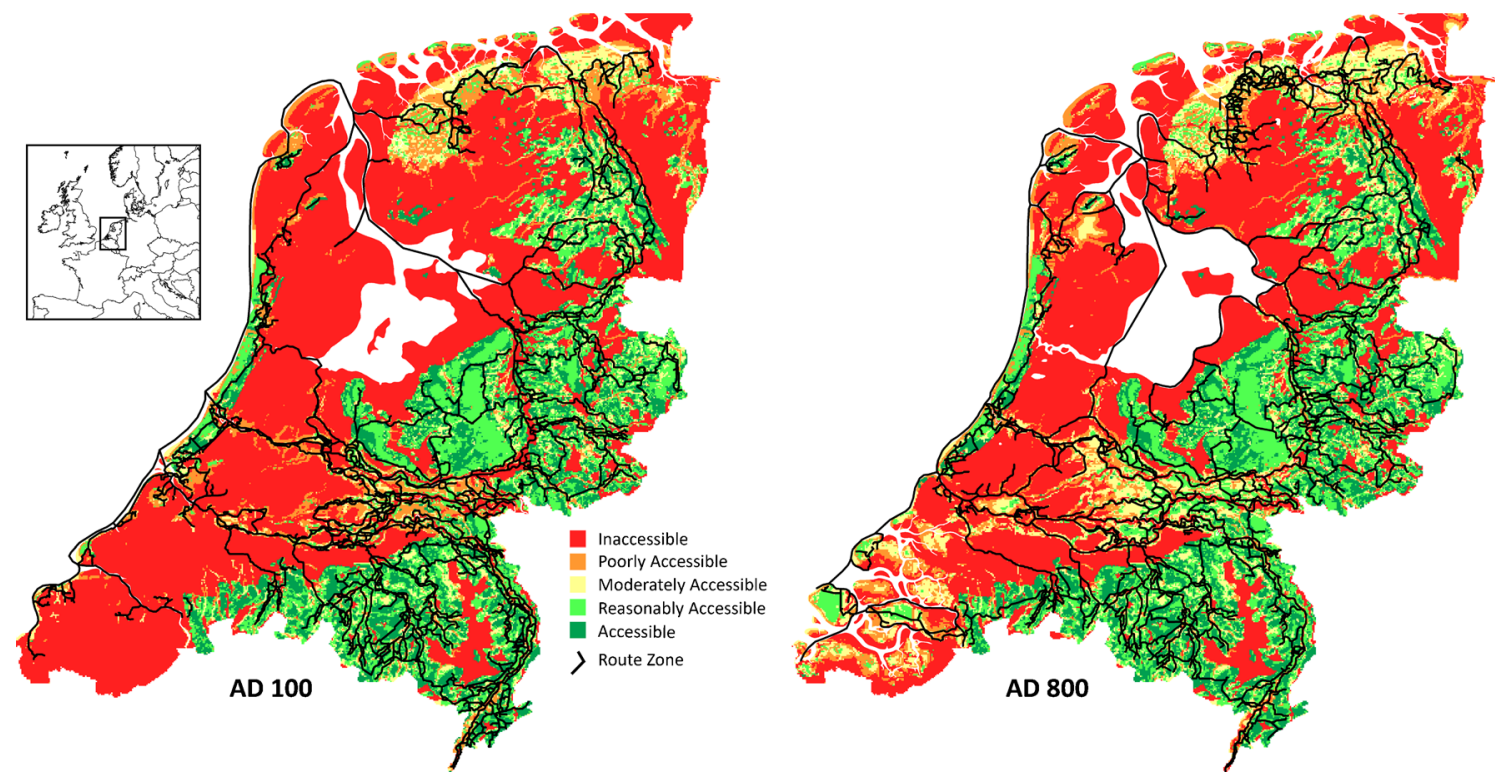

Fig. 1 Route networks (land and water) overlaid on network-friction maps of the Netherlands: AD 100 and 800 (adapted from Van Lanen et al. (2015a, b))

based on old maps, this historical road atlas of Doorgaande wegen in Nederland, 16e tot 19 e eeuw reconstructs the major interregional routes in the Netherlands for the periods around AD 1600, AD 1800 and AD 1848. Horstens' main assumption while creating this atlas was that old maps covering these periods provide contemporaneous data on road networks. Horsten selected the interval AD 1600-1848 since in the Netherlands, no detailed old maps are available dating before AD 1600 and since after AD 1848, railways were responsible for the majority of interregional land transport. Furthermore, the infrastructure of later periods is incomparable because of the rise of modern international market economies (e.g. Wallerstein 2004).

\section{Method}

\section{Digitizing early-modern road networks}

The historical road network of AD 1600 was digitized based on the historical road atlas of Horsten (2005) ("Historical road data" section). Data was geo-referenced using the Netherlands National coordinate System, Amersfoort/RD new-EPSG:28992. Results were overlain on the TMK 1850 maps in GIS (Figs. 2 and 3i, ii). Historical landscape elements still visible on the TMK 1850 maps were compared to the road network in order to determine correlating roads (Fig. 2). By using this method, it was possible to digitize the complete road network.

We already established the fundamental difference between road and route networks ("Theoretical background" section). In order to analyse persistence between route networks reconstructed by Van Lanen et al. (2015b) and the road network reconstructed by Horsten (2005), the latter was converted to a route network with equal $500-\mathrm{m}$ wide route zones (i.e. the highest possible accuracy) (Fig. 3ii).

\section{Calculating route persistence}

\section{Route networks on a supra-regional scale}

Whereas the EMT route network covers the Netherlands as a whole, the ROM and EMA networks exclude the southern part of Limburg due to methodological reasons, i.e. in this area, relief and soil conditions are incomparable with other parts of the study area (Van Lanen et al. $2015 \mathrm{a}, \mathrm{b})$. In order to determine route persistence between the three periods, Limburg was also removed from the EMT dataset. Since route persistence is based on spatial correlation between route sections, the three networks were converted to individual lines. A varying route-section length is not a problem with route zones of $500 \mathrm{~m}$ wide, as long as the average does not exceed the maximum deviation of $1000 \mathrm{~m}$ (which equals two parallel grid cells). In GIS, the spatial correlations between the route sections were calculated using the following query:

ROM_Land_Routes_250.Obj intersects EMA_Land_Routes $250.0 b j$

This query selects those ROM route sections that intersect with the EMA dataset. For this example, a 250-m buffer (i.e. 500-m route zone) was used. EMA-ROM and EMT-EMA persistence was calculated using the most accurate $250-\mathrm{m}$ buffer (Fig. 3iii). 


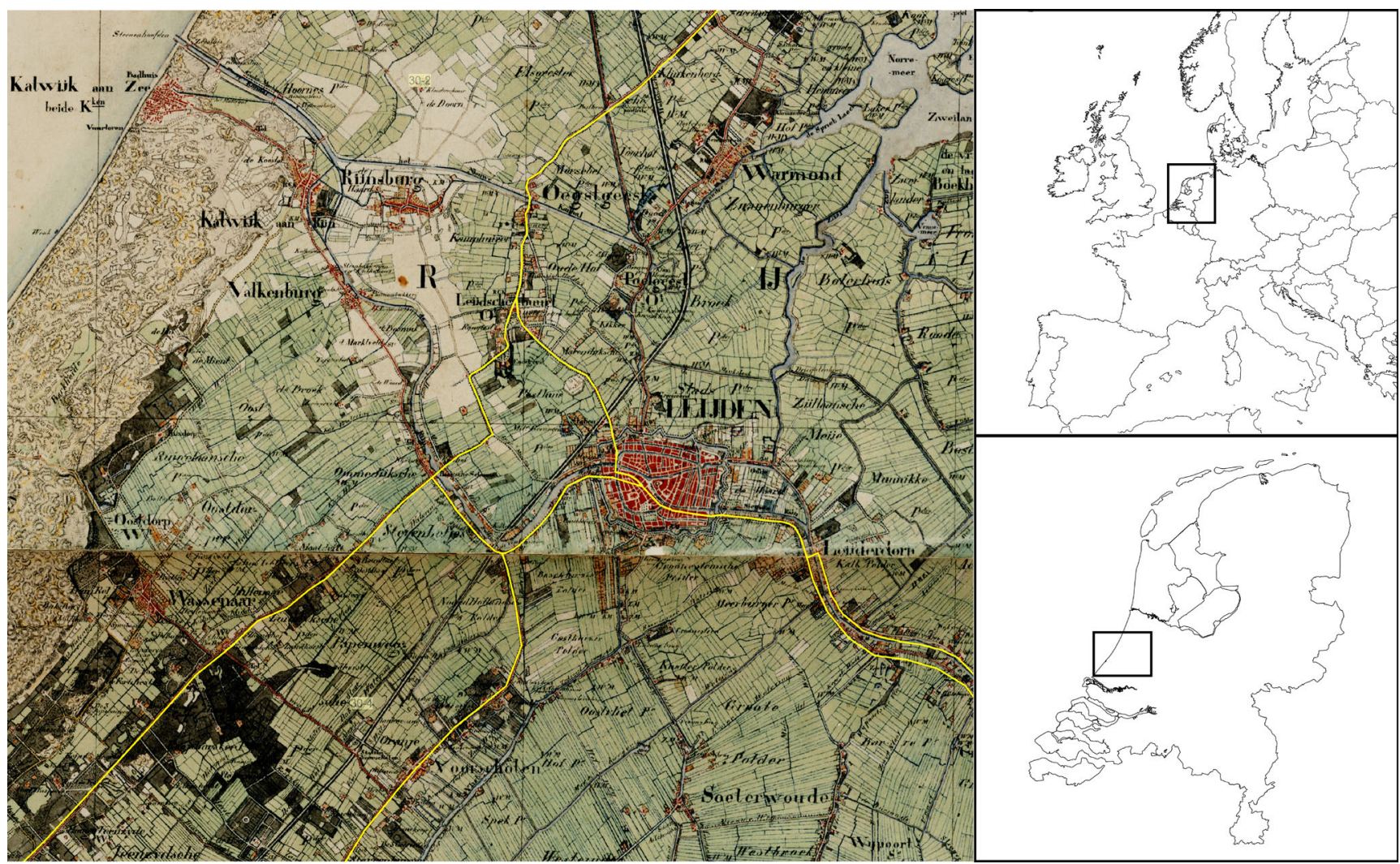

Fig. 2 Digitization of the Horsten (2005) historical road data. Elements on the topographic military maps of 1850 were identified as roads (pre) dating AD 1600 (yellow)

\section{Route networks in dynamic and less dynamic landscapes}

The Holocene parts of the Netherlands are commonly regarded as geomorphologically more dynamic than the Pleistocene soils because of the strong influence of both marine and fluvial processes. To calculate the impact of these dynamics on route persistence in the Netherlands, a separation between Holocene and Pleistocene regions was applied to the analyses (Fig. 3iii). Boundaries of these soils were determined using the newly developed Archaeological Landscapes Map of the Netherlands. In GIS, the route sections located on the Holocene or Pleistocene soils were selected and analysed separately. Route persistence was calculated for both regions using the same method applied to the supra-regional overview.

\section{Excluding anomalous routes}

There are major cultural differences between the ROM, EMA and EMT periods. Some of these are directly related to, and thus influence, route networks. For example, the Netherlands in the EMT period already had experienced large-scale reclamation activities (Borger 1992; De Bont 2008) and was governed by types of central administrations which were able to facilitate and maintain large infrastructural works. During the ROM and EMA periods, the majority of the Netherlands was still covered by extensive peat areas (Petzelberger et al. 1999) and, especially in the EMA period, a central administration was (virtually) non-existent. Therefore, the background of certain EMT routes is incomparable to those of the previous periods and these routes need to be excluded from the persistence calculations (Fig. 3iv).

Two types of anomalous routes could be differentiated for the EMT period: (a) routes situated on reclamation dikes and (b) the so-called hessenwegen. Many reclamation dikes are the product of large-scale reclamation activities which did not occur in the ROM and EMA periods. Since routes on reclamation dikes are positioned in previously inaccessible lands, they are incomparable to routes in previous periods. Therefore, in GIS, reclamation dikes were selected and removed based on anthropogenic elements as specified in the Archaeological Landscapes Map of the Netherlands. An exception was made for reclamation dikes located on already existing levees, since such levees would have constituted naturally accessible movement corridors prior to the EMT period.

The hessenwegen are best described as long-distance trade routes running in almost straight lines (as the crow 

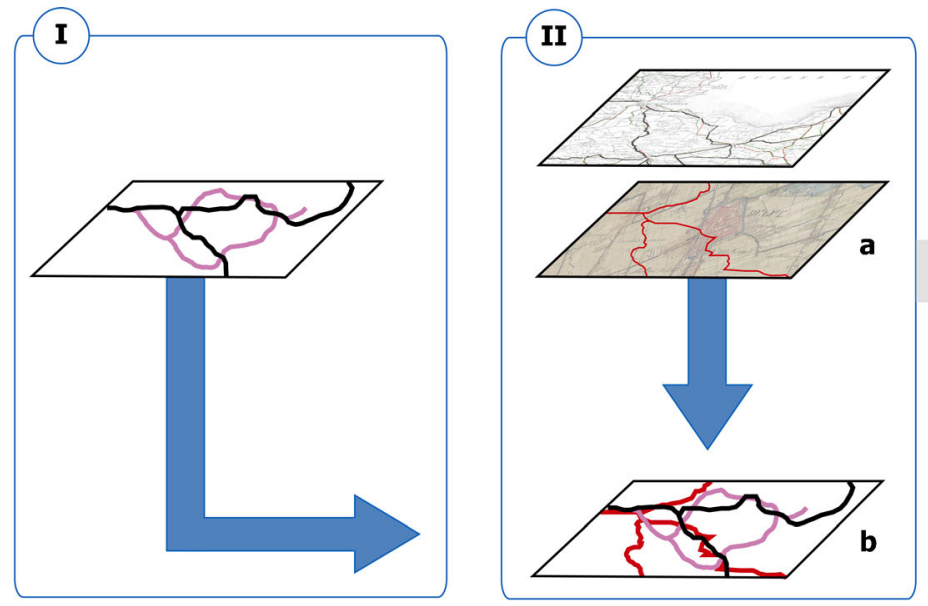

$$
\begin{aligned}
& \text { Roman and early-medieval route-network data } \\
& \text { from Van Lanen et al. (2015b) were imported } \\
& \text { into GIS. }
\end{aligned}
$$

II.

Data from Horsten (2005) on historical roads around AD 1600 in the Netherlands were

digitized using corresponding geographical 1850 (a) (TMK 1850). All thre darasets were integrated in GIS (b).

III.

Spatial correlation between Roman, early-medieval and early-post medieval (EPM) route networks was calculated on for the research area and the Holocene and Pleistocene areas.

IV.

Anomalous (man-made) routes (reclamation dikes (c), hesssenwegen (d)) post-dating the Early Middle Ages were removed from the EPM-route network and long-term persistence between the three route networks was calculated (e). Persistence values were recalculated (point III).

v.

Route networks were reanalysed using persistent places (f) (i.e. settlement in-use during both periods) and persistent movement corridors (g) (i.e. transport corridors based on network friction). Persistence values were recalculated (point III).
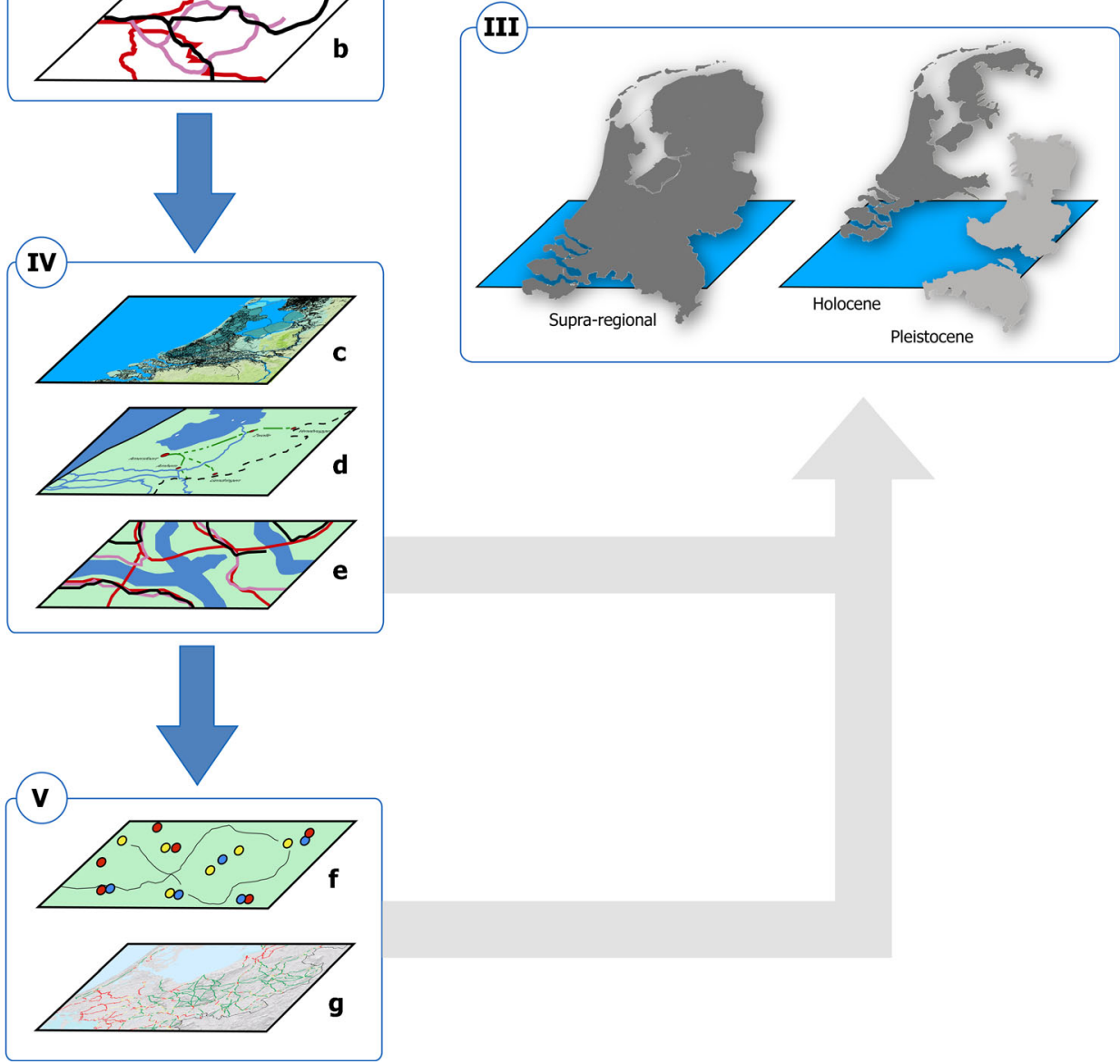

Fig. 3 Flowchart of route-persistence calculations. i ROM and EMA route network data from Van Lanen et al. (2015b) were imported into GIS. ii Data from Horsten (2005) were digitized using corresponding geographical structures from the TMK1850 maps $(a)$. All three datasets were integrated in GIS $(b)$. iii EMA-ROM and EMP-EMA persistence was calculated for the whole of the research area and separately for the constituting Holocene and Pleistocene parts. iv Anomalous routes:

reclamations dikes $(c)$ and hessenwegen $(d)$ postdating the EMA period were removed from EMT route network and long-term persistence between the three route networks was calculated (e). Persistence values were recalculated (iii). $\mathbf{v}$ Route networks were reanalysed using persistent places $(f)$ and persistent movement corridors $(g)$. Persistence values were recalculated (iii)

flies) through the landscape. These EMT routes were created to facilitate larger and wider carts travelling from and to Germany and were designed to connect cities and preferably avoid settlements (Leijden 1940; Fockema Andreae 1957). As such, the hessenwegen fundamentally differ from the modelled ROM (with the exception of the limes road) and EMA routes.

\section{Calculating long-term route persistence}

Long-term persistence (i.e. route sections persistent in three consecutive periods) was calculated for all route sections within the persistent route networks. By comparing the ROM, EMA and EMT route networks, we were able to localize long-term persistent route sections used in all three periods. 
Resulting persistent values were used to determine the ratio between long-term and short-term persistence (Fig. 3iv).

\section{Quantifying cultural and landscape dynamics}

Route orientation is influenced by cultural and/or natural dynamics. In order to model and understand the extent of, and ratio between, these types of influences, we analysed route persistence for two scenarios: one in which settlements between periods were non-dynamic and one where movement corridors were persistent through time.

\section{Persistent settlements}

Settlement patterns are dynamic through time. Settlement locations change as a response to, among others, changing environmental, economic, demographic and political conditions. Since ROM and EMA routes were calculated based on a combination of settlement patterns and network-friction values ("Past route networks" section), settlement shifts will automatically influence persistence results. In order to quantify the influence of dynamic settlement locations on persistence values, we reanalysed the existing route networks only using those route sections that connect persistent places (i.e. settlements that were in use during both periods) (Fig. 3v).

Persistent settlements were calculated based on the spatial correlation between settlements in, first, the ROM and EMA period and, second, the EMA and EMT period. Since settlement data from all three periods are point data, we used settled areas as defined by Van Lanen et al. (2015b) to select persistent places. We applied a concentric ring buffer of $1.019 \mathrm{~km}$ (according to Van Lanen et al. (2015b) the smallest and most accurate settled area) around each settlement and only included correlating settlements into the dataset. Route sections no longer connecting settlements were removed from the route network and persistence between the remaining, smaller networks was calculated.

\section{Persistent movement corridors}

Network-friction corridors for AD 800 movement already have been modelled by Van Lanen et al. (2015a). This dataset was used to quantify the influence of cultural dynamics on route orientation between the EMA and EMT periods. By comparing the EMT route network with the network-friction map of AD 800, we were able to calculate the percentage of routes following EMA network-friction corridors (Fig. 3v). The average network-friction value $(\mathrm{Nfv})$ for each route section was calculated in order to determine which section made use of $\mathrm{AD} 800$ corridors (i.e. moderately accessible to accessible grid cells; Nfv's: 3-5; Van Lanen et al. 2015a). Since in these corridors landscape prerequisites are suitable for routes in both the EMA and EMT periods, the difference between route persistence and the percentage of route sections running through these movement corridors is best explained by cultural differences between the two periods.

\section{Results}

\section{Supra-regional route-network persistence}

Results show that $67.6 \%$ of the EMA route network is persistent with route sections from the ROM period (Table 1). In the EMT period, $21.7 \%$ of the routes show persistence with EMA routes. In both periods, the majority of the persistent routes are located in the eastern part of the country (Fig. 4).

\section{Route networks in dynamic and less dynamic landscapes}

In the Holocene area, EMA-ROM and EMT-EMA route persistence is 64.6 and $15.4 \%$, respectively (Table 1). For the Pleistocene areas, the EMA-ROM network persistence is slightly higher than it is on a supra-regional scale: $69.3 \%$. EMT-EMA route persistence in the Pleistocene areas is remarkably higher, $30.2 \%$. Especially, the difference in persistence between the Holocene and Pleistocene areas (14.8\%) is remarkable.

\section{Persistence without anomalous routes}

Two types of anomalous, artificially constructed, routes were determined for the EMT period: reclamation dikes and hessenwegen. After filtering these anomalous routes from the EMT network, the 250-m buffer was reapplied. Since the EMA-ROM network was not altered, only EMT-EMA route persistence was recalculated (Table 2). On a supra-regional scale, persistence increased with 2.8\%. EMT-EMA route persistence for the Holocene area increased to $19.7 \%$ and for the Pleistocene area decreased to $26.5 \%$ (Fig. 5).

\section{Long-term persistence}

Long-term persistence was calculated for the EMA and EMT period route networks. Results show that $26.2 \%$ of the EMA network consists of long-term persistent route sections (Table 3). These sections were not only in use during the EMA period, but also during the ROM and EMT periods. This means that $38.8 \%$ of the EMA-ROM persistent route sections are long-term persistent (Fig. 5). The correlations for the EMT period are a bit weaker, with $21.8 \%$ of the route network being in use during all three periods (Table 3 ). Interestingly, this means that $88.9 \%$ of the EMT-EMA persistent route sections show long-term persistence (Fig. 5). 
Table 1 Overview of EMA-ROM and EMT-EMA persistence values (in bold). Percentages were calculated for the whole of the research area and the Holocene and Pleistocene areas separately

\begin{tabular}{lllllll}
\hline Period & $\begin{array}{l}\text { Surface } \\
\text { supra-regional }\left(\mathrm{km}^{2}\right)\end{array}$ & $\begin{array}{l}\text { Persistence }(\%) \\
\text { supra-regional }\end{array}$ & $\begin{array}{l}\text { Surface } \\
\text { Holocene }\left(\mathrm{km}^{2}\right)\end{array}$ & $\begin{array}{l}\text { Persistence }(\%) \\
\text { Holocene }\end{array}$ & $\begin{array}{l}\text { Surface } \\
\text { Pleistocene }\left(\mathrm{km}^{2}\right)\end{array}$ & $\begin{array}{l}\text { Persistence }(\%) \\
\text { Pleistocene }\end{array}$ \\
\hline ROM period & 1816.33 & 100.00 & 664.54 & 100.00 & 1164.45 & 100.00 \\
EMA period & 1481.32 & 100.00 & 559.13 & 100.00 & 946.64 & 100.00 \\
EMA-ROM & $\mathbf{1 0 0 1 . 2 9}$ & $\mathbf{6 7 . 5 9}$ & $\mathbf{3 6 0 . 9 5}$ & $\mathbf{6 4 . 5 6}$ & $\mathbf{6 5 6 . 2 2}$ & $\mathbf{6 9 . 3 2}$ \\
EMT period & 2538.10 & 100.00 & 993.87 & 100.00 & 1558.93 & 100.00 \\
EMT-EMA & $\mathbf{5 5 0 . 6 6}$ & $\mathbf{2 1 . 7 0}$ & $\mathbf{1 5 3 . 4 7}$ & $\mathbf{1 5 . 4 4}$ & $\mathbf{4 7 1 . 0 0}$ & $\mathbf{3 0 . 2 1}$ \\
\hline
\end{tabular}

\section{Persistent places and movement corridors}

Using persistent places, the EMA and EMT route networks were adapted to only include route sections that connect settlements inhabited both during the ROM and EMA periods. Using this approach, EMA-ROM route persistence on a supra-regional scale increases to $75.2 \%$. In the Holocene and Pleistocene areas, persistence increases to 80.5 and $72.3 \%$, respectively (Table 4 and Fig. 6). Especially, the high rise of persistence in the Holocene area $(15.9 \%)$ stands out.

EMT-EMA route persistence was calculated based on persistent places between the EMT and EMA periods. Results show a clear rise in persistence values: on a supra-regional scale EMT-EMA persistence increases to $29.4 \%$, and for the Holocene and Pleistocene areas, to 27.8 and $32.1 \%$, respectively (Table 4 and Fig. 6). Especially, the high rise of persistence in the Holocene areas $(12.4 \%)$ stands out.

We compared the EMT route network (excluding anomalous routes) with movement corridors modelled by Van Lanen et al. (2015b) in order to determine EMT-EMA persistence with EMA movement corridors. Results show that the $71.4 \%$ of the EMT route network runs through EMA movement corridors (AD 800) (Table 5 and Fig. 7). Since the EMT-EMA route persistence is $24.5 \%$, the difference between these two percentages (which is $46.9 \%$ ) is best explained by cultural differences between these periods. a

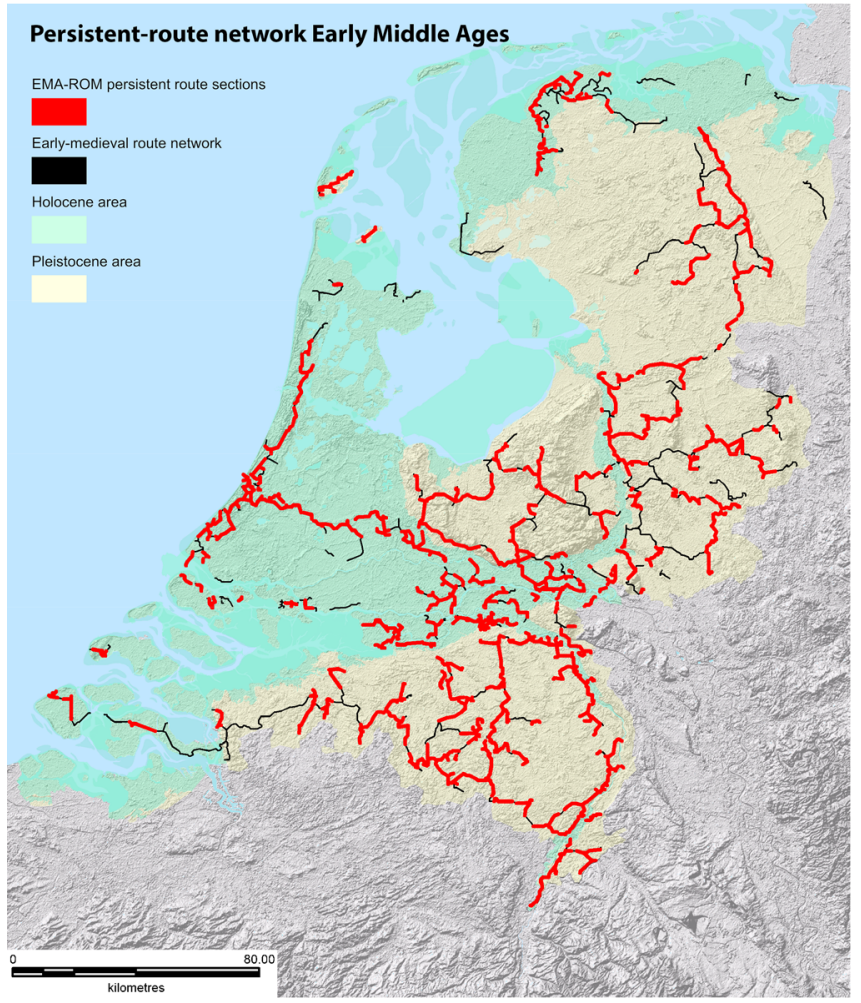

b

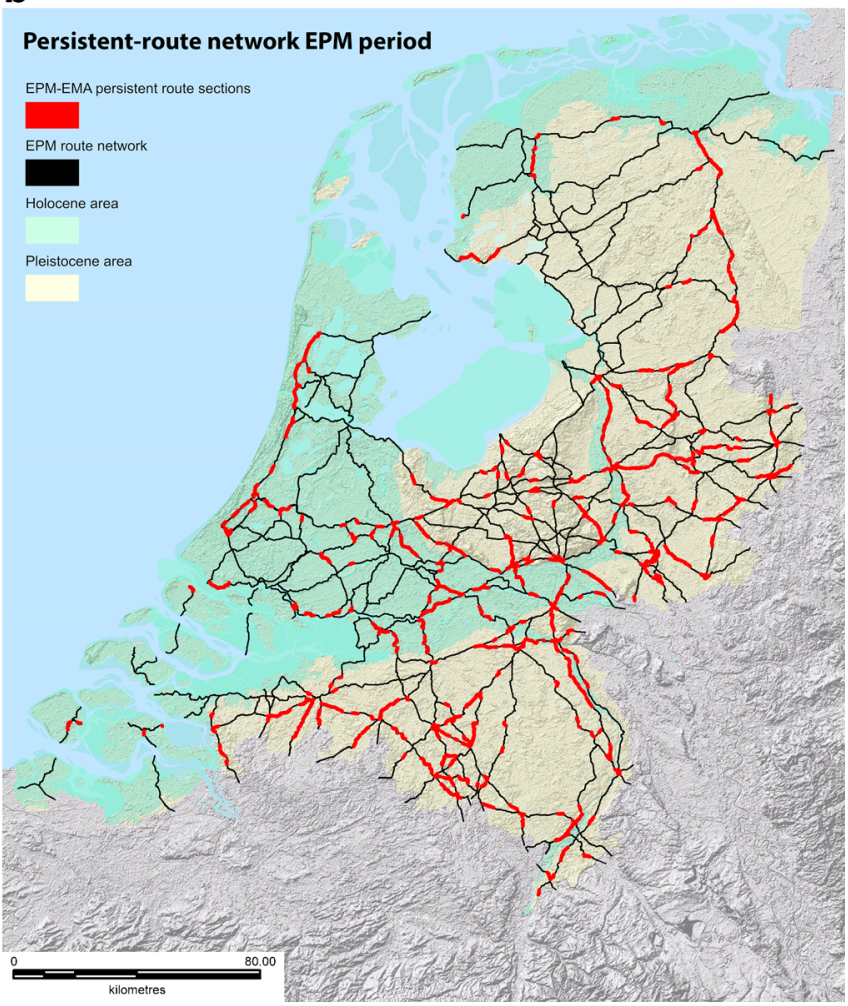

Fig. 4 a EMA-ROM persistent route network. EMA-ROM persistent route sections (red) are overlaid on the entire EMA route network (black). b EMTEMA persistent route network. EMT-EMA persistent route sections (red) are overlaid on the entire EMT route network (black) 
Table 2 Overview of filtered (i.e. without anomalous routes) EMA-ROM and EMT-EMA persistence values (in bold). Percentages were calculated for the whole of the research area and the Holocene and Pleistocene areas separately

\begin{tabular}{lllllll}
\hline Period & $\begin{array}{l}\text { Surface } \\
\text { supra-regional }\left(\mathrm{km}^{2}\right)\end{array}$ & $\begin{array}{l}\text { Persistence }(\%) \\
\text { supra-regional }\end{array}$ & $\begin{array}{l}\text { Surface } \\
\text { Holocene }\left(\mathrm{km}^{2}\right)\end{array}$ & $\begin{array}{l}\text { Persistence }(\%) \\
\text { Holocene }\end{array}$ & $\begin{array}{l}\text { Surface } \\
\text { Pleistocene }\left(\mathrm{km}^{2}\right)\end{array}$ & $\begin{array}{l}\text { Persistence }(\%) \\
\text { Pleistocene }\end{array}$ \\
\hline ROM period & 1816.33 & 100.00 & 664.54 & 100.00 & 1164.45 & 100.00 \\
EMA period & 1481.32 & 100.00 & 559.13 & 100.00 & 946.64 & 100.00 \\
EMA-ROM & $\mathbf{1 0 0 1 . 2 9}$ & $\mathbf{6 7 . 5 9}$ & $\mathbf{3 6 0 . 9 5}$ & $\mathbf{6 4 . 5 6}$ & $\mathbf{6 5 6 . 2 2}$ & $\mathbf{6 9 . 3 2}$ \\
EMT period & 2095.26 & 100.00 & 670.74 & 100.00 & 1449.10 & 100.00 \\
EMT-EMA & $\mathbf{5 1 3 . 6 0}$ & $\mathbf{2 4 . 5 1}$ & $\mathbf{1 3 2 . 2 7}$ & $\mathbf{1 9 . 7 2}$ & $\mathbf{3 8 3 . 4 1}$ & $\mathbf{2 6 . 4 6}$ \\
\hline
\end{tabular}

\section{Discussion}

Datasets developed by Horsten (2005) and Van Lanen et al. (2015a, b) allow us to study the stability of route networks. In this paper, we quantified route persistence as an expression of cultural and natural dynamics. On a supra-regional scale, we were able to calculate that $67.6 \%$ of the EMA routes sections are persistent with Roman counterparts. Percentages drop considerably towards the EMT period, with only $21.7 \%$ of the supra-regional route network showing persistence (Table 1
Fig. 5 EMT-ROM persistent route network. Long-term persistent (blue) and EMT-EMA persistent route sections ( $r e d$ ) are overlaid on the entire EMT route network in which anomalous routes were removed (black)

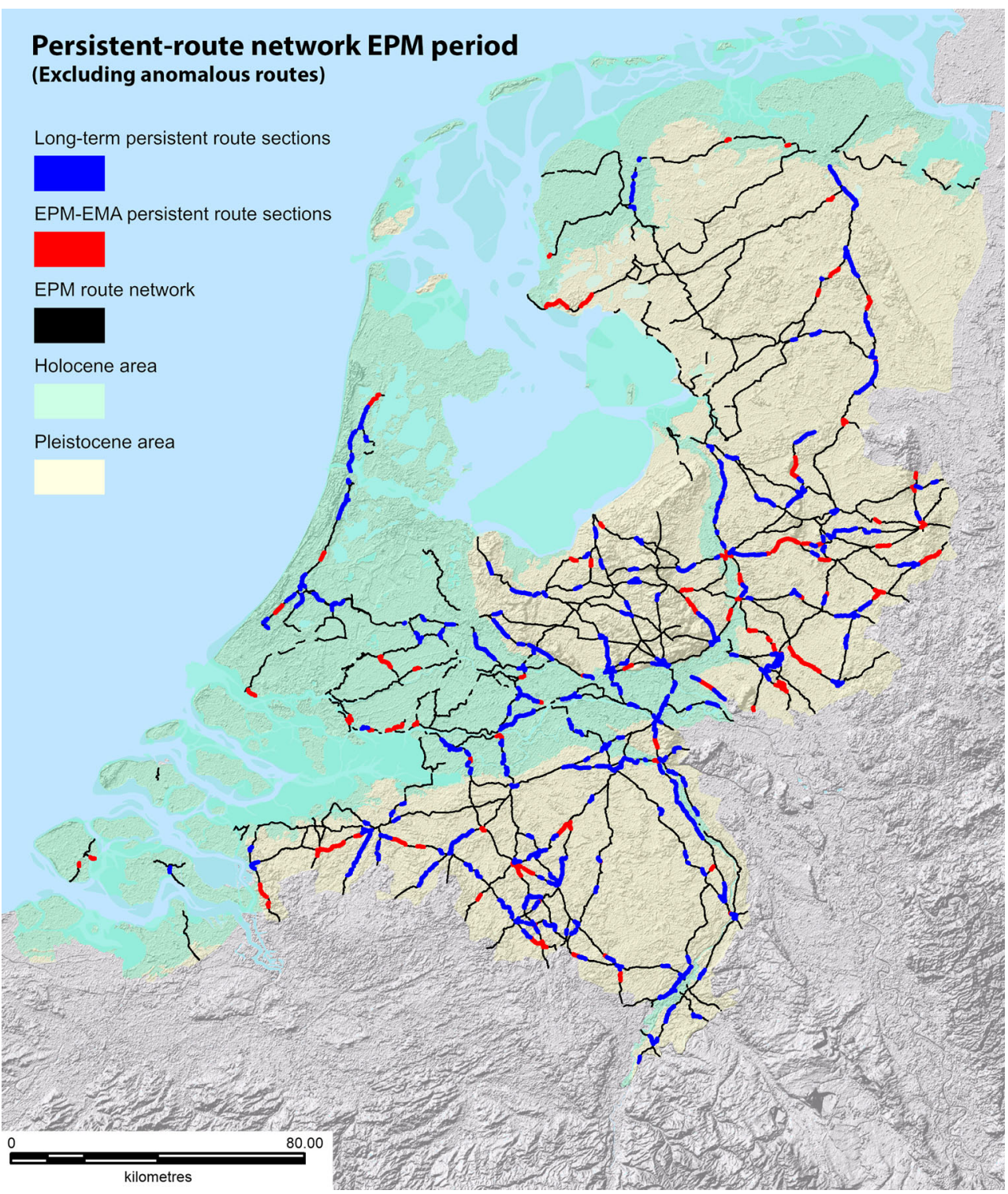


Table 3 Long-term route persistence in the Netherlands. ROM, EMA and EMT route networks were compared to calculate long-term persistent sections (bold) within the EMA and EMT networks

\begin{tabular}{lll}
\hline Complete route network & Surface supra-regional $\left(\mathrm{km}^{2}\right)$ & Percentage supra-regional (\%) \\
EMA period & 1481.32 & 100.00 \\
Long-term persis_EMA & $\mathbf{3 8 8 . 0 2}$ & $\mathbf{2 6 . 1 9}$ \\
EMT period & 2095.26 & 100.00 \\
Long-term persis_EMT & $\mathbf{4 5 6 . 5 0}$ & $\mathbf{2 1 . 7 9}$ \\
Persistent route network & Surface supra-regional $\left(\mathrm{km}^{2}\right)$ & Percentage supra-regional (\%) \\
EMA period & 1001.29 & 100.00 \\
Long-term persis_EMA & $\mathbf{3 8 8 . 0 2}$ & $\mathbf{3 8 . 7 5}$ \\
EMT period & 513.60 & 100.00 \\
Long-term persis_EMT & $\mathbf{4 5 6 . 5 0}$ & $\mathbf{8 8 . 8 8}$ \\
\hline
\end{tabular}

and Fig. 4). This drop is not unexpected since the EMT route network connects a much larger number of settlements. Also, the EMA and EMT are not culturally consecutive. Therefore, there is an increased likelihood of fundamental landscape and c changes to have occurred.

When looking at EMA-ROM persistence in the Holocene and Pleistocene areas, it becomes clear that persistence in the Holocene areas is slightly lower than it is at the supra-regional level and that in the Pleistocene areas it is slightly higher (Table 1 and Fig. 4). However, the difference of $4.7 \%$ between both areas is relatively small. It would seem that although the Holocene area is more dynamic, routes crossing this area generally were bound to relatively stable movement corridors (e.g. past levees). EMT-EMA persistence between the Holocene and Pleistocene areas differs much more strongly (14.8\%) (Table 1 and Fig. 4). This gap is best explained by large-scale reclamation activities starting in the tenth century in Holocene areas, reducing the influence of natural landscape conditions on route orientation ("Theoretical background" section).

Routes (and their origin) can differ considerably. Religious, economic, political and military purposes may have influenced route orientation. Van Lanen et al. (2015b) did not differentiate between different types of ROM and EMA routes. They modelled routes based on network friction and used deviating routes (e.g. sections of the limes road) for validation purposes only. Therefore, anomalous routes from the EMT period were removed from the dataset. These anomalous routes (i.e. hessenwegen and reclamation dikes) were artificial constructs that were more or less independent of landscape conditions ("Calculating route persistence" section). Since only the EMT route network contains these anomalous routes, EMA-ROM persistence did not change. On a supra-regional level due to this adaptation EMT-EMA persistence increased by $2.8 \%$ and for the Holocene area it increased to $19.7 \%$ (Table 2 and Fig. 5). Remarkably persistence in the Pleistocene areas decreased by $3.7 \%$, which leads to the hypothesis that hessenwegen at least in part must have followed the orientation of pre-existing routes.
Persistence in this paper was calculated between three route networks. In these networks, no differentiation was made between primary, secondary and tertiary routes or settlements. In addition, the individual networks represent routes that were in use during the entire, or at least part, of the analysed periods. Therefore, some routes are shown as being in use during the entire period, but actually might have never co-existed with other routes in the network. Calculations therefore show the maximum amount of persistence between the different networks.

Long-term persistence was calculated for route sections that were in use during all three periods. Although much lower than the previously calculated EMA-ROM and EMT-EMA persistence (26.2 and $21.8 \%$, respectively), these percentages do represent the part of the route network that is more persistent then other sections (Table 3 and Fig. 5). Translating these percentages to the complete EMA and EMT route networks leads to some interesting results. EMA-ROM persistence was calculated at $67.5 \%$, of which only $38.7 \%$ is long-term persistent. EMT-EMA persistence is much lower, $24.5 \%$, of which a remarkable $88.9 \%$ represents long-term persistent route sections. It seems that this specific part of the route network was active in all three periods, and could - theoretically-have been used continuously.

In order to determine the influence of settlement dynamics on route-network persistence, the networks were adapted to only include and connect persistent places ("Quantifying cultural and landscape dynamics" section). As a result, on a supra-regional scale, EMA-ROM persistence increased by $7.6 \%$ (Table 4 and Fig. 6). Persistence increased in the Holocene as well as the Pleistocene areas. The remarkable rise of EMA-ROM persistence in the Holocene areas (by 15.9\%) is best explained by the apparent influence of marine and fluvial dynamics on settlement patterns in these parts. EMTEMA persistence values also rose; supra-regionally, the values increased by $7.7 \%$. EMT-EMA persistence for the Holocene and Pleistocene areas also increased (Table 4 and Fig. 6). Again, the persistence values for the Holocene area stand out $(12.4 \%)$, which in this case is best explained by 


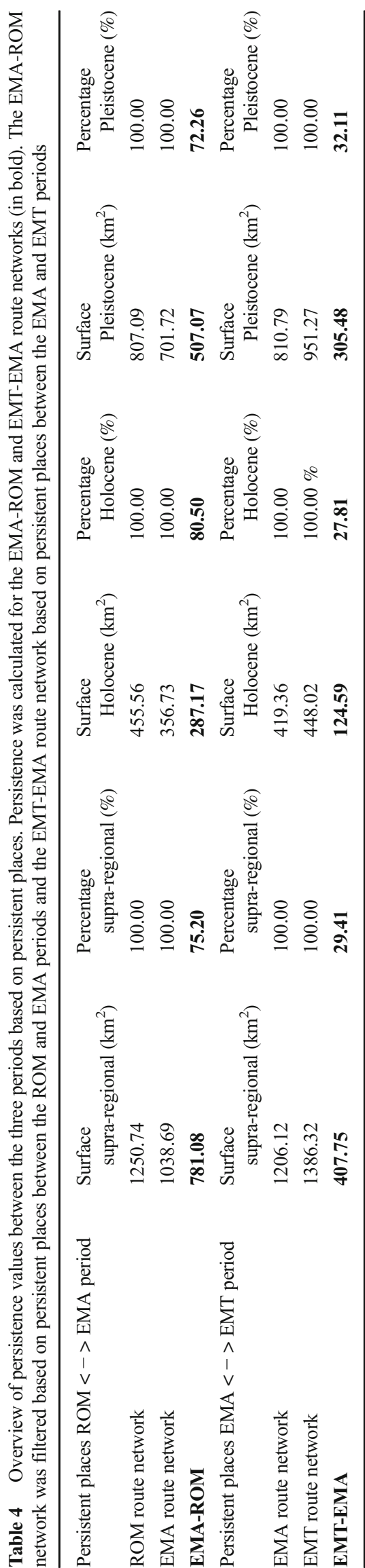

reclamation activities in many of these areas (large-scale embankments).

By comparing the EMT route network with movement corridors calculated through network friction, the average $\mathrm{Nfv}$ for each individual route section was determined. Results show that $71.4 \%$ of the EMT route network was located on movement corridors that already existed in AD 800 (Table 5 and Fig. 7). Since persistence between the EMA and EMT route network was $24.5 \%$, the difference of $46.9 \%$ can only be explained by cultural differences between the two periods. Cultural differences between the EMA and EMT periods are numerous and in part must have influenced route-network development. These changes include, but are not limited to the following: (1) changes in the realm of geo-politics, i.e. changing political borders; (2) socio-economics, e.g. changing transport, market functions and trade networks; (3) technological innovations (e.g. improved ploughing, reclamation, route formation techniques); (4) improved drainage and soil cultivation and (5) demographic rise. Within the current model, it is impossible to determine the nature or contribution of any specific cultural factor. The current model therefore should be regarded as a first step in determining the spatial extent of processes of route-network persistence. By expanding the model with high-resolution data on changing demography, settlement and socio-economic patterns in the future, our understanding of the contributions of these factors in routenetwork development could be further improved.

The datasets of Van Lanen et al. (2015a, b) are based on a grid-cell resolution of $500 \times 500 \mathrm{~m}$. Therefore, the highest possible accuracy level is a $500-\mathrm{m}$ wide route zone. Modelling results would benefit from a more detailed gridcell resolution. This would not only allow a more accurate modelling of network friction, possible route networks and persistence values, but also a better comparison to the digitized road system reconstructed by Horsten (2005).

As stated before, route networks in the Netherlands are determined through the complex interplay between cultural and environmental factors. Routes connect individual settlements, which are spatially dynamic through time. Settlements shifted continuously between the ROM, EMA and EMP periods. This poses no problem when applying the methodology presented in this study, since these settlement dynamics never exceeded the spatial resolution of the model developed by Van Lanen et al. (2015a, b).

Since no data on EMT water routes were available at the time of this study, persistence calculations were limited to land route networks only. Van Lanen et al. (2015b) defined route networks as a combination of water and land routes, in which both play an important and integral role. To fully determine route-network stability during the studied time interval, water routes might be modelled for the EMT period and integrated into the persistence analyses. 
a

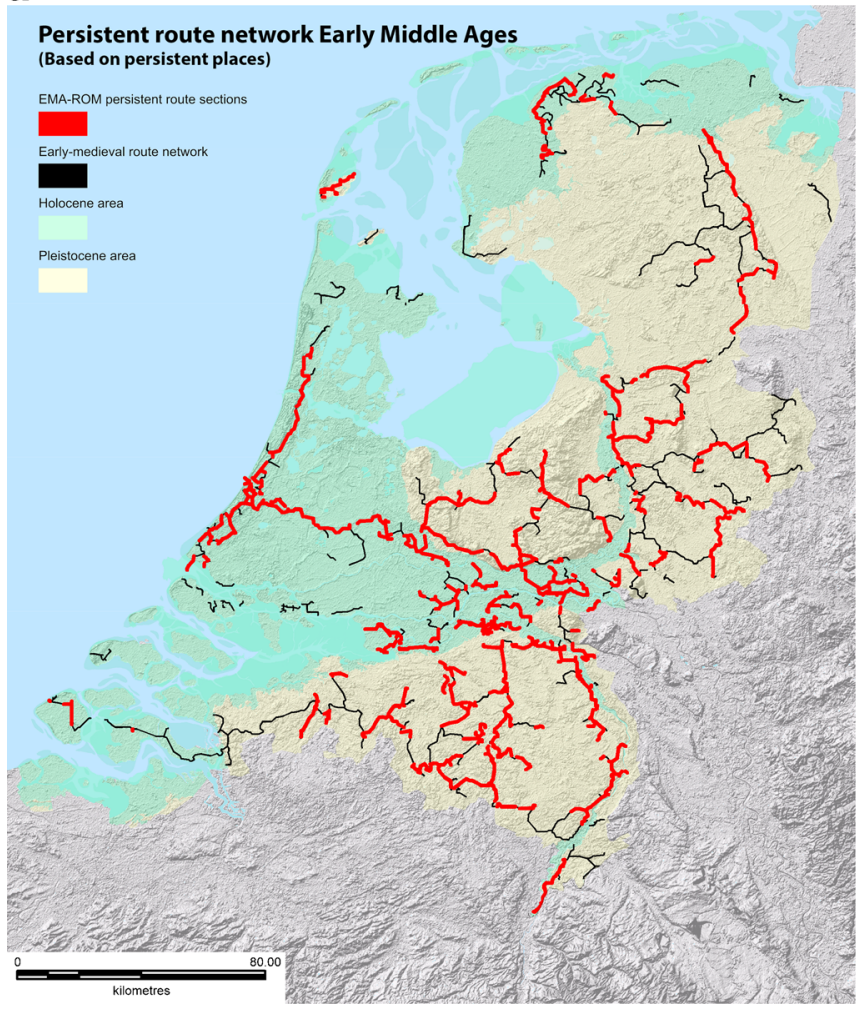

Fig. 6 a EMA-ROM persistent route network. EMA-ROM persistent route sections $(r e d)$ are overlaid on an EMA route network which is minimized to only include and connect persistent places (black). b

At present, no data on supra-regional vegetation development are available in the study area for the periods around $\mathrm{AD}$ 100,800 or 1600 . However, large parts of the research area must have been characterized by relatively low vegetation, due to (1) anthropogenic influences (e.g. increased woodcutting from the Iron Age onwards, farming) or (2) environmental conditions (e.g. marine marshes, oligotrophic and mesotrophic peat bogs). At the same time, visibility (i.e. the vicinity to distinguishable landmarks such as churches, specific land formations, large trees or swamps) generally appear to have been an integral part of past route-network formation and detailed

Table 5 Overview of the EMT route sections running through specific AD 800 network-friction values $(N f v)$. Total route-network surface is set to be 100 . Network friction is subdivided into 5 levels. Van Lanen et al. (2015a) regard Nfv 3-5 as indicative of movement corridors

\begin{tabular}{lll}
\hline $\begin{array}{l}\text { EMT route sections and } \\
\text { network-friction values (Nfv) }\end{array}$ & Surface $\left(\mathrm{km}^{2}\right)$ & Percentage (\%) \\
\hline EMT route network total & 2095.26 & 100 \\
EMT route network Nfv 1-2 & 677.39 & 28.6 \\
EMT route network Nfv 3 & 471.96 & 20.5 \\
EMT route network Nfv 4-5 & 1202.83 & 50.9
\end{tabular}

$1=$ inaccessible, $2=$ poorly accessible, $3=$ moderately accessible, $4=$ reasonably accessible and $5=$ accessible b

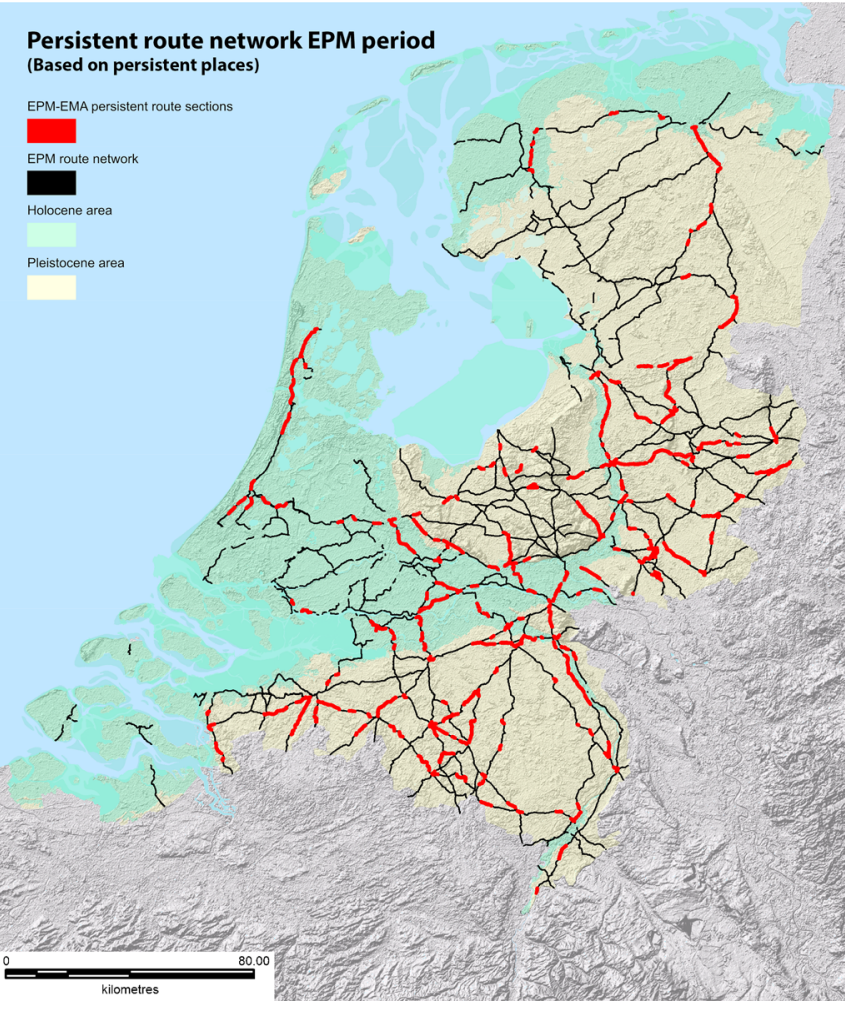

EMT-EMA persistent route network. EMT-EMA persistent route sections (red) are overlaid on an EMT route network which is minimized to only include and connect persistent places (black)

vegetation reconstructions in line with Van Beek et al. (2015) should be developed covering the complete study area. These data can then be incorporated into the route-network modelling, which would greatly improve modelling results and persistence calculations.

The term persistence in this paper has been defined as the spatial correlation between route sections during two different periods. However, the question remains how culturally meaningful the concept of persistence is when covering nonconsecutive periods. Additionally, the link between continuity and persistence should be explored further. This is, however, only beneficial when persistence is calculated with a higher resolution and for more (sub) periods ("Conclusion" section).

Persistence calculations in this paper were limited to determining spatial correlations between route networks. However, future research may reveal to what extent persistence also could hint at continuity. Does the occurrence of persistent route sections in a region also suggest an increased chance of continuous habitation and use of the network in this region? To what extent can persistence calculations be used to predict and improve our understanding of the characteristics and scientific potential of certain archaeological and historical sites? Could our persistence approach even allow for the localisation of areas with habitation (dis) continuity? Detailed regional studies into persistent route networks could answer these questions. 
Fig. 7 Based on the networkfriction map of AD 800 by Van Lanen et al. (2015a), persistent movement corridors were calculated for EMT route sections. Green and yellow lines depict movement corridors; red shows route sections of the EMT route network running through regions unsuitable for routes in $\mathrm{AD} 800$

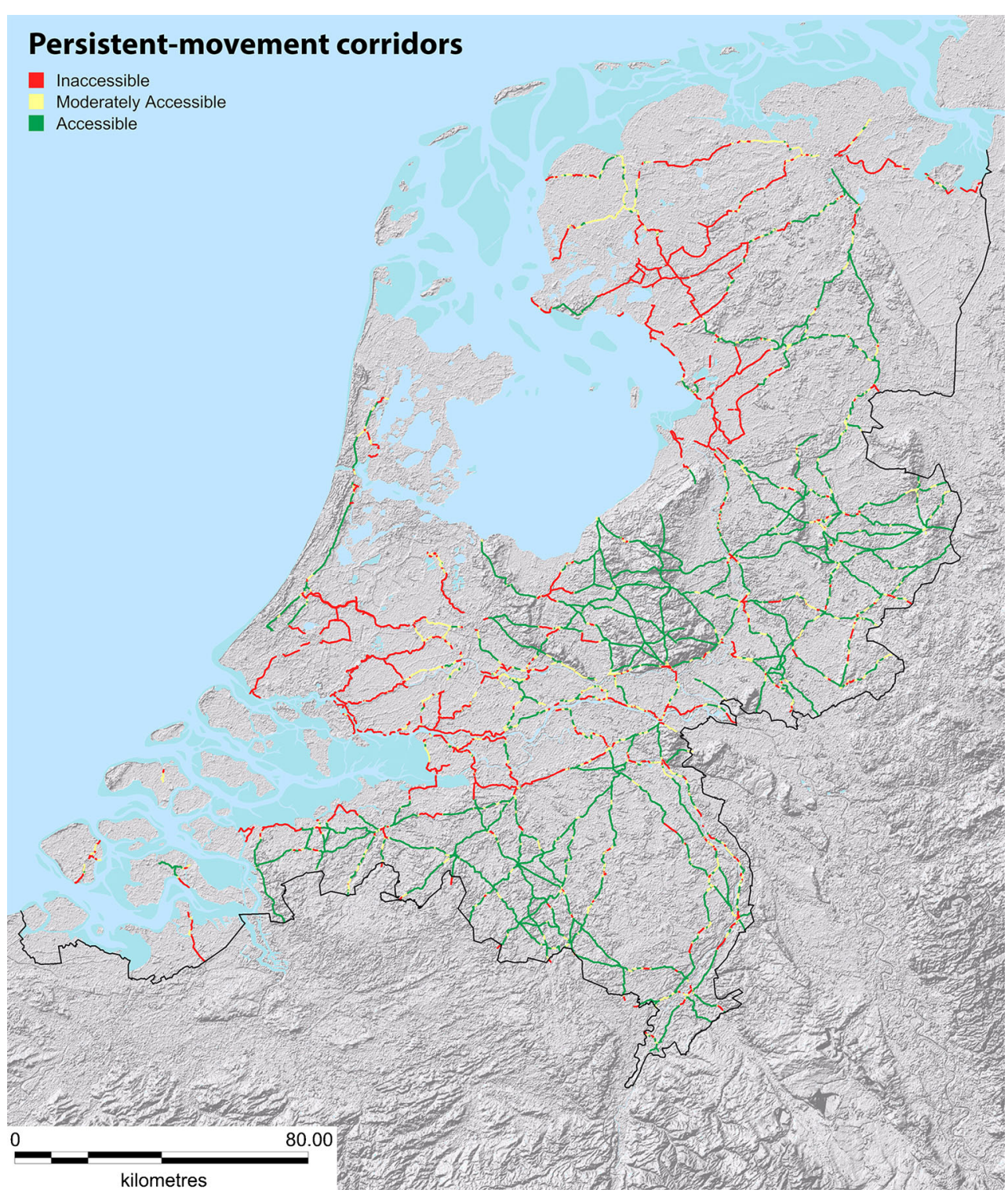

The current results are limited to the ROM, EMA and EMT periods. In order to determine the full potential of (long-term) persistence calculations, the number of compared periods should be increased. This would provide a chronological overview of changes in persistence throughout our research area and in addition would lead to the identification of sections of the current, modern road network in the Netherlands that correlate with older counterparts, adding further chronological depth to our understanding of the present-day road network.

The current models calculate route-network persistence solely based on spatial correlations between route sections. In addition to increasing the chronological resolution of the applied models, it could be worthwhile to apply a multitude of path or road network modelling techniques on the models' outcome. Since persistence-route sections reflect route zones of $500 \mathrm{~m}$ wide, these corridors can be used for more specific modelling of spatially more restricted features such as road, track or path structures. Especially for the Pleistocene parts of the study area, the analysis of high-resolution LIDAR data could prove promising to extract and relatively date remnants of past networks (c.f. Vletter 2014, Vletter and Van Lanen in review). Additionally, persistence reconstructions could benefit from multiple geostatistical analyses, e.g. sensitivity and uncertainty analysis (cf. Brouwer Burg et al. 2016), in order to determine the possible statistical significance of persistency in the study area. But also other techniques such as dynamic modelling, viewshed analysis, network analysis and agentbased modelling might help to increase our understanding of route-network evolution and long-term persistence. However, overcoming the challenges of applying these methods on a supra-regional scale would require an enormous increase in data resolution.

Some long-term persistent route sections appear to have a more or less isolated spatial position within the network 
(Fig. 5). Areas in between these long-term persistent sections should be studied more extensively. Detailed archaeological analyses might prove routes in these areas to be more persistent then currently modelled and could provide us with more insight in settlement dynamics.

\section{Conclusion}

This paper describes a new research approach that was developed to shed light on changing route networks and settlement patterns between the ROM and EMA periods and to what extent the outcome of these changes is apparent in later periods? In this study, we did not use data to substantiate a hypothesis. Instead, we introduced new quantifying methods to objectify and spatially illustrate the dynamic processes that (may have) underlaid route-network differences between the ROM, EMA and EMT periods. By integrating data from "classic" archaeological research with new systematic, quantitative, objectified and evidence-based methods, these changes were localized and quantified. This study represents a first step in this type of data integration, and the promising results hint at the necessity of a follow-up in which the base-data quality and model resolution are increased.

Persistence as defined in this study increases our understanding of changing settlement distribution patterns. Persistent route networks only occur in regions where cultural (e.g. economic, political) and landscape conditions are relatively stable. Therefore, persistence may be used to determine and calculate settlement (in)stability. By quantifying the stability of route networks, it is thus possible to increase our understanding of past processes of cultural and landscape change.

The evidence-based approach using large-scale datasets propagated in this study neatly fits with the way forward in archaeological method and theory as was recently advocated by Kristiansen (2014). The proposed method facilitates a detailed comparison and analysis of individual datasets. Through this approach probable data hiatuses could be identified and missing data could be extrapolated. For example, by comparing EMT occupation patterns with the network-friction map of AD 800, it became clear that certain movement corridors, currently not part of the EMT route network, most probably did have routes. Additionally, comparing the different route networks also results in the identification of regions most likely to contain undiscovered settlements and thus deserving more focussed archaeological research. The combination of datasets greatly improves our understanding of settlement patterns for each individual period.

The evidence-based approach to route-network stability increases our understanding of historical reality. Long-term persistence calculations show route sections that may indicate the presence of (as yet) undiscovered persistent places. These long-term persistent routes are not randomly distributed across the country but are located in specific regions, enveloping many of the oldest historical cities (e.g. Alkmaar, Arnhem, Deventer, Haarlem, Leiden, Nijmegen, Zwolle). In this respect, long-term persistence might well be a suitable tool for localizing multiple-period archaeological sites. Investigated such sites is crucial to increase our understanding of past processes of environmental and cultural change.

Acknowledgements This study is part of research program, The Dark Age of the Lowlands in an interdisciplinary light: people, landscape and climate in the Netherlands between AD 300 and 1000, which is funded by the Netherlands Organisation for Scientific Research (NWO, section Humanities; 2012-2018; project number 360-60-110). We would like to thank Prof.dr. H Renes (Utrecht University and VU University Amsterdam) and dr. J.E. Abrahamse, drs. E. Raap and drs. M. A. Lascaris (Cultural Heritage Agency of the Netherlands) for their invaluable help in reconstructing habitation and socio-cultural patterns for the Early Modern Times in the Netherlands. We are very grateful to drs. M. C. Kosian for his support with GIS data integration.

Open Access This article is distributed under the terms of the Creative Commons Attribution 4.0 International License (http:// creativecommons.org/licenses/by/4.0/), which permits unrestricted use, distribution, and reproduction in any medium, provided you give appropriate credit to the original author(s) and the source, provide a link to the Creative Commons license, and indicate if changes were made.

\section{References}

Barker G (1986) L'archeologia del paesaggio italiano: nuovi orientamenti e recenti esperienze. Archeologia Medievale 13:7-29

Bechert T, Willems WJH (1995) De Romeinse rijksgrens tussen Moezel en Noordzeekust, Utrecht

Borger GJ (1992) Draining - digging — dredging; the creation of a new landscape in the peat areas of the low countries. In: Verhoeven JTA (ed) Fens and bogs in the Netherlands: vegetation, history, nutrient dynamics and conservation, Geobotany, vol 18, pp. 131-171

Bos IJ (2010) Distal delta-plain successions. Architecture and lithofacies of organics and lake fills in the Holocene Rhine-Meuse delta plain, The Netherlands, $\mathrm{PhD}$ thesis Utrecht University, Utrecht

Brand GBM, Crombaghs MJE, Oude Elberink SJ, Brügelmann R, de Min EJ (2003) Precisiebeschrijving AHN 2002, Rijkswaterstaat AGI

Brouwer Burg M, Peeters H, Lovis W (2016) Uncertainty and sensitivity analysis in archaeological computational modeling. Springer

Cohen KM, Stouthamer E, Pierik HJ, Geurts AH (2012) Digitaal Basisbestand Paleogeografie van de Rijn-Maas Delta/RhineMeuse Delta Studies' Digital Basemap for Delta Evolution and Palaeogeography. Dept. Physical Geography. Utrecht University (digital dataset). http://persistent-identifier.nl/?identifier= urn:nbn:nl:ui:13-nqjn-zl

Council of Europe (2000) European landscape convention, Florence 2010-2000. European Treaty Series 176. Florence

De Bont C (2008) Vergeten land. Ontginning, bewoning en waterbeheer in de westnederlandse veengebieden (800-1350). PhD Thesis Wageningen University and Research Centre, Wageningen

De Vries F, de Groot WJM, Hoogerland T, Denneboom J (2003) De bodemkaart van Nederland digitaal; Toelichting bij inhoud, actualiteit en methodiek en korte beschrijving van additionele informatie, Alterra-rapport 811, Wageningen 
Dijkstra M (2011) Rondom de mondingen van Rijn \& Maas. Landschap en bewoning tussen de $3^{e}$ en $9^{e}$ eeuw in Zuid-Holland, in het bijzonder de Oude Rijnstreek, $\mathrm{PhD}$ thesis University of Amsterdam, Amsterdam

Erkens G (2009) Sediment dynamics in the Rhine catchment Quantification of fluvial response to climate change and human impact, $\mathrm{PhD}$ thesis Utrecht University, Utrecht.

Fairclough G (2007) Understanding and using the diversity of landscape; English experiences, in: Council of Europe: Fourth meeting of the Council of Europe Workshops for the implementation of the European Landscape Convention, Ljubljana Slovenia, 11-12 May 2006, pp. 41-57

Fockema Andreae SJ, (1957) Hessenwegen, Mededelingen der Koninklijke Nederlandse Akademie der Wetenschappen, afdeling Letterkunde, Nieuwe reeks, deel 20, nr. 11, pp. 283-301

Gerding MAW (1995) Vier eeuwen turfwinning. De verveningen in Groningen, Friesland, Drenthe en Overijssel tussen 1550 - 1950, $\mathrm{PhD}$ thesis Wageningen University and Research Centre, A.A.G. Bijdragen 35, Wageningen

Gerrets DA (2010) Op de grens van land en water. Dynamiek van landschap en samenleving in Frisia gedurende de Romeinse tijd en de volksverhuizingstijd, $\mathrm{PhD}$ Thesis Groningen University, Groningen

Herzog I (2014) Least-cost Paths - some methodological issues. Internet Archaeology (36) 10.11141/ia.36.5

Herzog I (2013a) Theory and practice of cost functions. In: Contreras F, Farjas M, Melero FJ (eds) Fusion of cultures. Proceedings of the 38th Annual Conference on Computer Applications and Quantitative Methods in Archaeology, Granada, Spain, April 2010, BAR International Series 2494 (Granada 2013), pp. 375-282

Herzog I (2013b) Least-cost networks. In: Earl G, Sly T, Chrysanthi A, Murrieta-Flores P, Papadopoulos C, Romanowska I, Wheatley D (eds) Archaeology in the digital era. CAA 2012, proceedings of the 40th Annual Conference of Computer Applications and Quantitative Methods in Archaeology (CAA), Southampton, pp. 240-251

Herzog I (2013c) Calculating accessibility. In: Earl G, Sly T, Chrysanthi A, Murrieta-Flores P, Papadopoulos C, Romanowska I, Wheatley D (eds) Archaeology in the Digital Era. Volume II, e-Papers from the 40th Conference on Computer Applications and Quantitative Methods in Archaeology, Southampton, pp. 720-734

Herzog I, Posluschny A (2011) Tilt-slope-dependent least cost path calculations revisited. In: Jerem E, Redö F, Szeverényi V (eds) On the road to reconstructing the past. Proceedings of the 36th CAA conference 2008 in Budapest, pp. 212-218 (on CD: pp. 236-242)

Horsten FH (2005) Doorgaande wegen in Nederland, $16^{\mathrm{e}}$ tot $19^{\mathrm{e}}$ eeuw. Een historische wegenatlas, Amsterdam

Jansma E, Gouw-Bouman M, Van Lanen R, Pierik HJ Cohen K, Groenewoudt B, Hoek W, Stouthamer E, Middelkoop H (2014) The Dark Age of the Lowlands in an interdisciplinary light: people, landscape and climate in The Netherlands between AD 300-1000, European Journal of Post - Classical Archaeologies (PCA 4) ISSN: 2039-7895, pp. 471-476

Kluiving SJ, Guttmann-Bond E, (eds.) (2012) Landscape archaeology between art and science: From a multi- to an interdisciplinary approach. Amsterdam

Kluiving SJ, Lehmkuhl F, Schütt B (2012) Landscape archaeology at the LAC 2010 conference. Quarternary International 251:1-6

Knol E (1993) De Noordnederlandse Kustlanden in de Vroege Middeleeuwen, $\mathrm{PhD}$ thesis VU University Amsterdam, Amsterdam

Koomen AJM, Excaltus RP (2003) De vervlakking van Nederland; naar een gaafheidkaart voor reliëf en bodem, Alterra-rapport 740 , Wageningen

Koomen AJM, Maas GJ (2004) Geomorfologische Kaart Nederland $(\mathrm{GKN})$; Achtergronddocument bij het landsdekkende digitale bestand, Alterra-rapport 1039, Alterra research institute, Wageningen

Kristiansen K (2014) Towards a new Paradigm? The Third Science Revolution and its Possible Consequences in Archaeology, Current Swedish Archaeology, vol. 22, pp. 11-34.

Lascaris MA, de Kraker AMJ (2013) Dikes and other hydraulic engineering works from the Late Iron Age and Roman period on the coastal area between Dunkirk and the Danish Bight, In: Thoen, E., Borger, G., de Kraker, A.M.J., Soens, T., Tys, D., Vervoet, L., \& Weert, H.J.T. (eds.) Landscapes or seascapes? The history of the coastal environment in the North Sea area reconsidered. CORN Publication Series, 13, 177-198

Leijden F, (1940) Oude wegen op de Veluwe, in: Gelre, Vereeniging tot beoefening van Geldersche geschiedenis, oudheidkunde en recht, Bijdragen en mededeelingen, deel 43, Arnhem, 93-152

Lower Germanic Limes (LGL) World Heritage Database (2010) Der Deutschen Limeskom and the Cultural Heritage Agency of the Netherlands (RCE). Developed by: Bödecker S, van Marrewijk D, Kosian K, de Groot T, Hazenberg T More information: Bödecker S, Van Marrewijk D (2010) Auf dem Weg zum Welterbe? Internationale Tagung zum Niedergermanischen Limes, Nachrichtenblatt der Deutschen Limeskommission 4 (1), München

Miedema M (1983). Vijfentwintig eeuwen bewoning in het terpengebied ten noordoosten van Groningen, $\mathrm{PhD}$ thesis VU University Amsterdam, Amsterdam

Murrieta-Flores P (2012) Understanding human movement through spatial technologies. The role of natural areas of transit in the Late Prehistory of South-western Iberia, Trabajos de Prehistoria $69 \mathrm{nr}$. 1, pp. 103-122

Petzelberger BEM, Behre K-E, Geyh MA (1999) Beginn der Hochmoorentwicklung und Ausbreitung der Hochmoore in Nordwestdeutschland-Erste Ergebnisse eines neuen Projektes. Telma, Berichte der Deutschen Gesellschaft für Moor- und Torfkunde 29:21-38

Roorda IM, \& Wiemer R (1992). The ARCHIS Project: Towards a New National Archaeological Record in the Netherlands, in: Larsen, C. (ed.) Sites and Monuments: National Archaeological Records. The National Museum of Denmark. Copenhagen, pp. 117-122

Rutten R, IJsselstijn M (2014) 1000-1500 - Stadswording aan waterwegen: de grote stedenboom, In: Rutten, R. \& Abrahamse, JE. (eds.) Atlas van de verstedelijking van Nederland. 1000 jaar ruimtelijke ontwikkeling, TOHT, Bussum, pp. 170-185

Schlanger SH (1992) Recognizing persistent places in Anasazi settlement systems. In: Rossignol J, Wandsnider L (eds) Space, time, and archaeological landscapes. Plenum Press, New York, pp. 91-112

Steur GGG, \& Heijink W (eds.) (1991) Bodemkaart van Nederland. Schaal 1:50000. Algemene begrippen en indelingen, $4^{\text {de }}$ uitgave, Wageningen

Stouthamer E, Berendsen HJA (2000) Factors controlling the holocene avulsion history of the rhine-meuse delta (The Netherlands). J Sediment Res 70(5):1051-1064

Swart LMTh. (2010) How the Up-to-data Height Model of the Netherlands (AHN) became a massive point data cloud. Management of massive point cloud data: wet and dry. Nederlandse commissie voor Geodesie, Delft

Toonen WHJ (2013) A holocene flood record of the lower rhine, Utrecht Studies in Earth Sciences 41, PhD thesis Utrecht University, Utrecht

Van Beek R (2009) Reliëf in Tijd en Ruimte. Interdisciplinair onderzoek naar bewoning en landschap van Oost-Nederland tussen de vroege prehistorie en middeleeuwen, $\mathrm{PhD}$ thesis Wageningen University, Wageningen

Van Beek R, Gouw-Bouman MTIJ, Bos JAA (2015) Mapping regional vegetation developments in Twente (the Netherlands) since the late glacial and evaluating contemporary settlement patterns. Neth J Geosci:1-27. doi:10.1017/njg.2014.40 
Van der Gaast JWJ, Vroon HRJ, \& Massop HThL (2010) Grondwaterregime op basis van karteerbare kenmerken. STOWA rapportnummer 2010-41, Amersfoort

Van der Linden JA, (1973) Topographische en Militaire kaart van het Koningrijk der Nederlanden, Bussum 1973

Van der Velde HM (2011) Wonen in een grensgebied, $\mathrm{PhD}$ thesis VU University Amsterdam. Nederlandse Archeologische Rapporten (NAR), 40, Amersfoort

Van der Zon N (2013) Kwaliteitsdocument AHN2, Delft

Van Dinter M (2013) The Roman Limes in the Netherlands: how a delta landscape determined the location of the military structures. Neth J Geosci 92-1:11-32

Van Lanen RJ, Kosian MC, Groenewoudt BJ, Jansma E (2015a) Finding a way: modeling landscape prerequisites for roman and earlymedieval routes in the Netherlands. Geoarchaeology: An international Journal 30:200-222

Van Lanen RJ, Kosian MC, Groenewoudt BJ, Spek T, Jansma E (2015b) Best travel options: modelling Roman and early-medieval routes in the Netherlands using a multi-proxy approach, Journal of Archaeological Science: Reports 3 (JASR), pp. 144-159

Van Tielhof M, Van Dam P (2006) Losing land, gaining water. Ecological and financial aspects of regional water management in Rijnland, 1200-1800. In: Greefs, H \& 't Hart, M (eds.): Water management, communities and environment. The low countries in comparative perspective, c. 1000- c. 1800. Jaarboek voor Ecologische Geschiedenis 2005/2006, pp 63-93

Verhagen P (2013) On the road to nowhere? Least cost paths, accessibility and the predictive modelling perspective. In: Contreras F, Farjas M, Melero JF (eds) Proceedings of the 38th Annual Conference on Computer Applications and Quantitative Methods in Archaeology . Archaeopress, Oxford, Granada, Spain, pp. 383-390April 2010

Verlinde AD, Hulst RS (2010) De grafvelden en grafvondsten op en rond de Veluwe van de Late Bronstijd tot in de Midden-IJzertijd, Nederlandse Archeologische Rapporten (NAR), 39, Amersfoort

Verwers WJH (1998) North Brabant in Roman and Early Medieval Times. Habitation History. $\mathrm{PhD}$ thesis VU University Amsterdam, Amersfoort

Vletter W, (2014) (Semi) automatic extraction from Airborne Laser Scan data of routes and paths in forested areas. In: SPIE proceedings Second International Conference on Remote Sensing and Geoinformation of the Environment 9229:92291D August 2014. DOI: $10.1117 / 12.2069709$

Vletter WF, Van Lanen RJ, (in review) Finding 'Hidden' Routes. Applying a Multi-Modelling Approach on Lost Route and Path
Networks: an Example from the Veluwe Region in the Netherlands, Rural Landscapes

Vos PC (2015) Origin of the Dutch Coastal landscape; Long term landscape evolution to the Netherlands during the Holocene, described and visualized in national regional and local palaeographical map series, $\mathrm{PhD}$ Thesis Utrecht University, Utrecht

Vos PC, Van Heeringen RM (1997) Holocene geology and occupation history of the Province of Zeeland (SW Netherlands), in: Fischer, M.M., (ed.) Holocene evolution of Zeeland (SW Netherlands), Mededelingen Nederlands Instituut voor Toegepaste Geowetenschappen (Netherlands Institute of Applied Geosciences, TNO) 59, pp 5-109

Vos PC, De Vries S (2013) 2e generatie palaeogeografische kaarten van Nederland (versie 2.0). Deltares, Utrecht

Vos PC, Bazelmans J, Weerts HJT, \& Van der Meulen HJT (eds.) (2011) Atlas van Nederland in het Holoceen, Amsterdam

Wallerstein I (2004) World-systems analysis. An introduction, Duke University Press

Wiemer R (2002) Standardisation: the key to archaeological data quality, In: García Sanjuan L. \& Wheatley D.W. (ed.). Mapping the Future of the Past, Managing the Spatial Dimension of the European Archaeological resource, Sevilla, pp 103-108

Wolters-Nordhoff (1990) Grote Historische Atlas van Nederland, 4 dln., Groningen

Zakšek K, Fovet E, Nunniger L, Podobnikar T (2008) Path modelling and settlement pattern. In: Poluschny A, Lambers K, Herzog I (eds) Layers of perception. Proceedings of the 35 th International Conference on Computer Applications and Quantitative Methods in Archaeology (CAA). Habelt, Bonn, pp. 309-315

On-line data sources (accessed on 25-05-2015)

Archaeological Information System of the Netherlands (ARCHIS) https://archis.cultureelerfgoed.nl/\#/login

OpenStreetMap dataset www.openstreetmap.org

Histland datasets http://landschapinnederland.nl/bronnen-enkaarten/histland

Archaeological Landscapes Map of the Netherlands $\mathrm{http}: / /$ archeologieinnederland.nl/bronnen-en-kaarten/archeologischelandschappenkaart 